\title{
Research Management Systems: Systematic Mapping of Literature (2007-2017)
}

\author{
Anabel Velásquez-Durán ${ }^{\# 1}$, María Soledad Ramírez Montoya ${ }^{\# 2}$ \\ \# Escuela de Humanidades y Educación, Tecnológico de Monterrey, \\ Av. Eugenio Garza Sada 250 Sur Col. Tecnológico, Monterrey, Nuevo León, 64849, México \\ E-mail: 'Iavelasquez@itesm.mx, ${ }^{2}$ solramirez@itesm.mx
}

\begin{abstract}
Research management in relation to Research and Development (R\&D) has found a comprehensive and powerful tool in the Current Research Information System (CRIS). Publications on the subject are still emerging, so knowing what research has been done and its contributions presents an opportunity to build theoretical and reference frameworks, and to identify gaps and potential opportunities for future developments in information technology. Various articles covering these systems were analyzed with the objective of identifying the research areas, countries and institutions in which they were published, as well as their research approaches, contributions and topics covered. A systematic mapping of literature was carried out, which included 33 articles published on Web of Science (WoS) and Scopus, from 2007 to 2017. To ensure valid results, the evaluation guide for researchers was used during for the design and review phases of the systematic mapping studies, as well as the corresponding evaluation rubric; in addition, a strategy to define direct decision rules on how to classify an article based on the results of evaluations of multiple researchers was adopted. The findings show that the main research areas are Information Science \& Library Science and Computer Science; the largest concentration of publications is found in Europe; research focuses on Evaluation Research; contributions are oriented to create processes and models, and to describe the applications and uses of CRIS. It is concluded that there are areas of opportunity for the development of research in this area, such as the expansion of the research areas in which it is used, the possibilities of collaboration, sharing and exchange at a global level, and the coverage towards integration issues with open access.
\end{abstract}

Keywords - Research management; current research information system; systematic mapping; technology; information system; information technology.

\section{INTRODUCTION}

CRIS (Current Research Information System) are systems that allow the efficient global management of all processes related to research and its derived information. They are information systems developed internally by an organization or acquired through an external provider, which aim to collect, analyze, inform, provide access and disseminate information related to Research and Development [1]. Furthermore, they allow to record and store the data sets resulting from the research [2], so they can be reused and accessed for monitoring and control purposes. Optimal storage, preservation, and exchange of this data are considered a keystone for the realization of Open Science and to address the need for immediate availability of metadata under the "FAIR" scheme: Findable, Accessible, Interoperable and Reusable [3]. CRIS is designed to manage information from heterogeneous data sources such as digital libraries, knowledge bases, and institutional repositories [4]; they also use standards such as CERIF (Common European Research Information Format) to manage and exchange data
[5], [6], and have their foundations in the work of the Community Research and Development Information Service (CORDIS). A CRIS, therefore, is a comprehensive system of scientific information, management, and analysis of the productivity of research.

As a system for information management, a CRIS can be useful in any area, sector or context. In such scenarios, they try to avoid the fragmentation of systems and to have available information (metadata and data) in a single format and in the same space, to evaluate the impact of science on society and to compare scientific activity among similar institutions [7]. A CRIS is related to all areas of the institution where it is implanted; however, they are mainly managed in those areas in which information services are created and where the research needs of the local academic communities and to the outside are answered [8]. CRIS must be installed and configured by a specialized IT team in such a way as to ensure its continuous use, and to provide technical support in case of eventualities. These systems are used for different environments, so it is necessary to have a multidisciplinary team for its operation, such as specialists in 
computer areas, mainly computer science and data administration.

A CRIS is an information system. To build one, it is necessary to use software engineering that provides tools and methods to build quality software within an established timeframe and budget [9]. On this subject, studies have been carried out using different research approaches [10], [11], [12]: Validation Research, Evaluation Research, Solution Proposal, Philosophical Papers, Opinion Papers and Experience Papers; all based initially on evaluation and classification criteria for engineering [13]. Therefore, a study in relation to the topic of CRIS can be classified within the research approaches used for software engineering.

Research on CRIS has made significant contributions to strengthen such systems and to ensure their interoperability. Contributions have been made regarding (a) processes that had allowed institutions to increase and enhance their publication count compared to previous years, when their collections were handled with a production virtually invisible to the community of specialists [14], [15]; (b) modeling, with the introduction of new publication models [16], including open access with the help of CRIS, which made it possible to establish links between individual researchers, their publications and the funding obtained; (c) development of frameworks [17] for the management of information associated with research, with a proposal to use the rapid application development method to design reusable modules and integrate frameworks to ensure the security and integration of the data [18]; (d) mapping and classifications, with proposals made for the conceptualization of science based on collaboration and mapping of the researchers' competencies [19], this type of information has been obtained from the SICRIS (Slovenian Current Research Information System), Slovenia's database of national research projects; (e) methods and tools, such as the evaluation of an exploratory project on new techniques for the development of collections at the University of Manchester Library [20], using innovative methods to ensure the construction of collections for the future and to promote automation, proposing a prospective method: to use its CRIS for the development of its collections. Also, the use of Symplectic Elements $\subseteq$ has also been reported as a tool to more efficiently measure the impact of their research. From this perspective, CRIS can provide a range of contributions that result in efficient data management, communication, and research evaluation.

Research on CRIS has been conducted on topics covering how they are integrated, their data structures and their components; applications; standards and protocols; even how they connect with institutional repositories. These systems are based on standards for their physical data models, XML message formats [21] and data exchange [22], so their data structure is essential to ensure interoperability. They employ a series of standards and protocols that guarantee interconnection with other systems; also, they are designed to manage homogeneous and heterogeneous data of institutional repositories or external resources like databases and libraries [4], and their main standard is CERIF. Another characteristic of CRIS is that they can be combined with institutional repositories [23] and perform an efficient exchange of information and reinforcement of their particular functions [24]. In addition, they have several applications, including their use in libraries and universities [25], [26], as well as in scientific communities [27]. The themes vary according to the research objectives of each institution publishing its results.

Research data has become a crucial topic of scientific communication and evaluation, so CRIS must be able to manage and take advantage of it [28]. The literature review shows that only a small number of studies (33 in total) are reported in the WoS and Scopus databases (2007-2017). This is an important gap in knowledge, since CRIS is gaining relevance as they are increasingly present in the internal infrastructure and management of research institutions, and have become a comprehensive tool with the possibility to expand (through interconnection with specific modules) to manage institutional, regional, national and international scientific production [29], [30], [31]. However, there is a lack of sharing and dissemination of the research results in this area. In light of these shortcomings, the value of this article lies in the fact that it allows to know what research has been carried out on this topic, in which areas, in which countries and institutions, under which research approach, its main contributions and topics, all of this to provide knowledge to build benchmarks and identify gaps and potential opportunities for future work in relation to the development, use, communication and interoperability and connection of CRIS with other systems, to the benefit of the global community of researchers and of society in general.

\section{MATERIALS AND METHOD}

A systematic mapping of literature was performed as a strategy to identify relevant studies about CRIS, their research approaches, main contributions and topics. Systematic mapping is used to obtain an overview of an area of research through the classification and counting of the contributions in that classification [32]. It aims to search the literature to find out which topics have been covered and in which publications they appeared. The research questions it employs are broad, as they seek to discover trends and gaps in research [12]. This study is supported by the systematic mapping process focused on the area of software engineering [11], [12], [33], and was performed in four phases, shown in Figure 1.

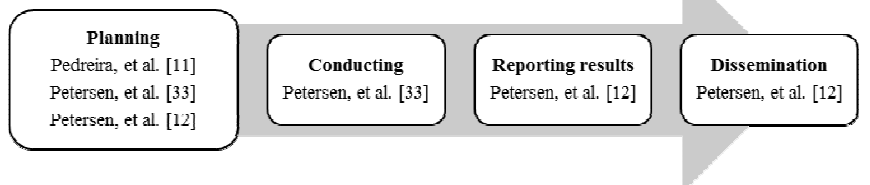

Fig. 1 Process of systematic mapping [34] (Based on [11], [12], [33])

\section{A. Phase 1: Planning}

Phase 1 consisted of making relevant decisions in advance of the mapping study based on prior knowledge to control the actions carried out and predict their consequences. The following tasks were performed:

1) Definition of Scope and Objective: The study was conducted to provide an overview of the scientific production of CRIS and to identify the quantity and type of research being carried out [33]. Also, we sought to identify research gaps in the existing literature and potential 
opportunities for future work on the subject [11]. For this purpose, relevant studies, their approaches, and their contributions and topics were extracted.

2) Definition of Research Questions: The research questions, shown in Table I, were defined based on the objectives [33].

TABLE I

RESEARCH QUESTIONS

\begin{tabular}{|l|l|}
\hline Number & \multicolumn{1}{c|}{ Questions } \\
\hline RQ1 & $\begin{array}{l}\text { How many studies have been published about } \\
\text { CRIS topics from 2007 to 2017? }\end{array}$ \\
\hline RQ2 & $\begin{array}{l}\text { In which areas of research have they been } \\
\text { published? }\end{array}$ \\
\hline RQ3 & $\begin{array}{l}\text { How many and in which countries studies related } \\
\text { to the topic have been conducted? In which } \\
\text { countries is there more production? }\end{array}$ \\
\hline RQ4 & $\begin{array}{l}\text { Which institutions or organizations have } \\
\text { published about this topic? }\end{array}$ \\
\hline RQ5 & $\begin{array}{l}\text { Which research approaches have been employed? } \\
\text { RQ6 }\end{array}$ \\
$\begin{array}{l}\text { What have been the main contributions that have } \\
\text { been made? }\end{array}$ \\
\hline RQ7 & $\begin{array}{l}\text { What are the main topics addressed and their } \\
\text { keywords? }\end{array}$ \\
\hline
\end{tabular}

3) Selection of Search Strategy: The strategy of literature search in databases was employed [12]. Specifically, two of the main bibliometric databases were used: Web of Science (WoS) and Scopus [35], [36], which have shown a high correlation between the number of documents and the number of citations received per country, and they are well known useful tools for science metrics analyses [37]. In addition, these resources have a multidisciplinary nature, are recognized as a source of relevant information by the international scientific community, and allow the export of data to bibliographic data management software [38]. WoS allows access to rigorously selected publications through a strict peer-review process of world-class journals, all through metadata and referenced citations, in addition to having links to regional citation indexes, patent data, indexes on specialized topics, research data and analysis tools [39]. Scopus includes citation data and peer-reviewed literature summaries of journals, books, and conference proceedings, and has smart tools for tracking, analyzing and visualizing research in the fields of science, technology, medicine, social sciences, and the arts and humanities [40]. Search strings or keywords based on the objectives [12] were also defined for this study (see Table II).

4) Definition of Inclusion and Exclusion Criteria: The criteria were identified based on the considered time frame, the type of document, the language and the relevance of the topic of the article [12], as shown in Table II.

\section{B. Phase 2: Implementation}

It consisted of implementing the defined search strategy during the planning phase, the analysis of the abstracts, the extraction of categories and their respective classification. Each task is detailed as follows [33].

1) Search for Primary Studies: Primary studies on CRIS were obtained by searching for keywords in the databases and applying the respective inclusion and exclusion criteria. In the case of WoS, the metadata was exported to a bibliographic management software (EndNote), creating a single set of records; in Scopus, it was exported in the CSV format, and both output files were opened in Microsoft Excel@ to delete duplicated records from both databases.

TABLE II

SEARCH AND STRATEGY STRINGS AND INCLUSION AND EXCLUSION CRITERIA

\begin{tabular}{|c|c|}
\hline Strategy & Description \\
\hline Databases & WoS and Scopus \\
\hline $\begin{array}{l}\text { Search string or } \\
\text { keywords }\end{array}$ & $\begin{array}{l}\text { "Current research information system" OR } \\
\text { "Current research information systems" in: } \\
\text { • WoS Database: Topic } \\
\text { • TOPIC: ("Current research information } \\
\text { system") OR TOPIC: ("Current } \\
\text { research information systems") } \\
\text { Refined by: DOCUMENT TYPES: } \\
\text { (ARTICLE) AND LANGUAGES: } \\
\text { (ENGLISH OR SPANISH) Timespan: } \\
\text { 2007-2017. Indexes: SCI- } \\
\text { EXPANDED, SSCI, A\&HCI, CPCI-S, } \\
\text { CPCI-SSH, BKCI-S, BKCI-SSH, } \\
\text { ESCI. } \\
\text { - Scopus Database: Article title, Abstract, } \\
\text { Keywords } \\
\text { • (TITLE-ABS-KEY ("Current research } \\
\text { information system") OR TITLE- } \\
\text { ABS-KEY ("Current research } \\
\text { information systems") ) AND } \\
\text { DOCTYPE (ar) AND PUBYEAR > } \\
\text { 2006 AND PUBYEAR < 2018 } \\
\text { AND (LIMIT-TO (LANGUAGE, } \\
\text { "English") OR LIMIT-TO } \\
\text { (LANGUAGE, "Spanish") ) AND } \\
\text { ( LIMIT-TO ( SRCTYPE, "j" ) ) }\end{array}$ \\
\hline Timeframe & 2007 - 2017 (June) \\
\hline $\begin{array}{l}\text { Type of } \\
\text { document }\end{array}$ & Article \\
\hline Language & English and Spanish \\
\hline Study field & Unspecified \\
\hline $\begin{array}{l}\text { Type of access } \\
\text { to the document }\end{array}$ & Unspecified \\
\hline $\begin{array}{l}\text { Inclusion } \\
\text { Were applied to } \\
\text { titles, abstracts } \\
\text { (and full text } \\
\text { when it was } \\
\text { necessary) }\end{array}$ & $\begin{array}{l}\text { - Primary studies about CRIS } \\
\text { - Studies were related to the CRIS topic in } \\
\text { any field (qualitative evaluation) } \\
\text { - Studies show the research approach } \\
\text { - Only articles published in journals. }\end{array}$ \\
\hline $\begin{array}{l}\text { Exclusion } \\
\text { Were applied to } \\
\text { titles, abstracts } \\
\text { (and full text } \\
\text { when it was } \\
\text { necessary) }\end{array}$ & $\begin{array}{l}\text { - Duplicated articles from the same research } \\
\text { - Articles presenting non-peer reviewed } \\
\text { material } \\
\text { - Studies not presented in English or } \\
\text { Spanish } \\
\text { - Studies weren't related to the CRIS topic } \\
\text { in any field. }\end{array}$ \\
\hline
\end{tabular}

The results from WoS and Scopus showed different criteria in the presentation of the metadata, which led to a standardization of the format, order and fields included. Also, the references could not be retrieved, so the information was collected directly from the articles. At the end of this process, 
a new single database was created, with information from each standardized item.

2) Keyword Analysis of Abstracts: This process consisted of three phases: (a) reading the abstracts to verify that the articles were related to the topic of CRIS in any field (qualitative evaluation), it should be noted that all the abstracts met this criterion; (b) identification of keywords and concepts that reflected the contribution and the topic covered, along with the research approach; and (c) combining the set of keywords to obtain representative categories and to understand the nature of the documents. For the evaluation and validation of the mapping, the evaluation guide for researchers during the design and review phases of systematic mapping studies was used [41], as well as the corresponding evaluation rubric [12]. For the topics of the extracted studies, the validation consisted of a strategy to define direct decision rules on how to classify an article based on the results of evaluations from multiple researchers, in this case, two independent from each other.

3) Creation of the Classification Scheme: Categories corresponding to each research question were established to classify the studies. Concerning the research approach (RQ5), a classification proposed in previous studies was adopted [13], which included: validation research, evaluation research, solution proposal, philosophical papers, opinion papers and experience papers. For the contribution made by the study (RQ6) and the topic covered (RQ7), the categories were based on the abstract and keywords analyses: cluster identification. In the first case, seven options were identified: framework, mapping, method, model, process, classification and tool; and for the second one, four options: data structure $(D S)$, applications (APP), communication / interoperability (INT), and institutional repositories (IR).

4) Data Extraction and Study Mapping: Each article was classified in the categories to which they belonged (data extraction). To document this process, a workbook was used in Microsoft Excel@ showing in each row the studies and in each column a category of the classification scheme. The resulting table was exported to SPSS@ (Statistical Package for the Social Sciences), a statistical analysis software used in the social sciences, with the objective of performing the descriptive analyses (frequencies) by categories to obtain a global vision of the CRIS, discover gaps and determine potential opportunities for future work on the subject. For the visualization of the frequencies, diverse graphs elaborated in Microsoft Excel $\odot$ and Tableau $\odot$ are presented.

\section{Phase 3. Results Report}

A general structure was used [12], which includes: an introduction with information about the topic's background, description of the need for systematic mapping, its usefulness and related works; research method; results presented according to the research questions and the discussion; conclusions and a references section.

\section{Phase 4. Dissemination}

The dissemination of the results report of the systematic mapping of the CRIS is carried out through a peer-reviewed article published in an indexed journal [12].

\section{RESULTS AND DISCUSSION}

\section{A. Search Results}

The search process was performed according to the strategy and the inclusion and exclusion criteria described in Table II. The results obtained are shown in Figure 2, including the qualitative evaluation (the first step of the analysis of the keywords of the abstracts). The 33 selected articles are available online at the following web address: http://doi.org/10.5281/zenodo.1094825 [42].

\section{B. Number of Publications (RQ1)}

From the search strategy designed in Table II, 33 articles were obtained from the WoS and Scopus databases for analysis. Figure 3 shows the distribution of these studies based on their year of publication, from 2007 to 2017.

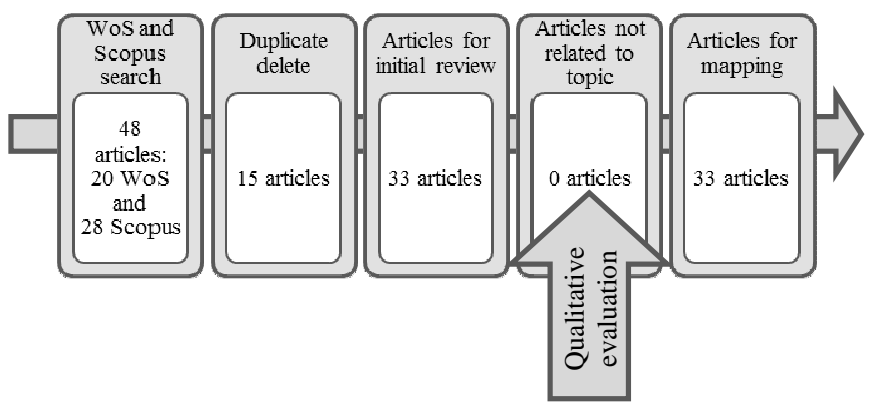

Fig. 2 Number of articles included during the search and qualitative evaluation process of the study [43]

CRIS is used consistently and sustainably for the management of research information. The data analyzed allowed us to find that the first study published was about the topic of Agriculture [44] and was the only article published in 2007. For 2009 there is no literature reported. In 2012 , the number of studies, five in total, is equivalent to all the production from 2007 to 2011; however, for 2013 it decreases again, increasing progressively between 2014 and 2016, being the latter the year with the highest production. From these studies, it was observed that CRIS are considered tools to enhance the management of information related to the research and dissemination of science, as well as to provide immediate availability to such information and promote communication and interoperability with others systems [1], [2]. They are also considered a viable option to carry out the management of research information as an instrument for decision-making, for access to scientific production and its dissemination, for the management of the research process itself, for the performance evaluation of the institutions in this area, and for the evaluation of the impact outside of the sectors or contexts it originates from.

\section{Research Areas (RQ2)}

From the metadata obtained from WoS and Scopus for each article and the global approach of the journal in which they were published, it was possible to identify the research area of analyzed studies, as shown in Table III.

The exposure and dissemination of CRIS-related knowledge lean towards the research areas of Information Science \& Library Science and Computer Science. The 33 articles analyzed show that $48 \%$ of the publications fall into 
the first category and 33\% fall into the second category (Table III and Figure 3). The highest number of publications in the Information Science \& Library area were made in 2014, while for Computer Science, it was in 2016. This makes sense to the extent that these systems require that specialists be involved in the process of building or implementing software and, of course, in its operation, such as computer experts, skilled in the management and administration of information and associated services [8], and able to help assess the impact of the publications generated [7]. Also, low production was observed in other areas of knowledge, specifically in the area of Education, as only one article is registered. The challenge is to generate original and cutting-edge research in the various areas of research related to CRIS to maximize their potential, share framework, models, standards, protocols, identifiers and best practices to integrate a global community that can share their research results with transparency.

In addition, Table IV provides a general overview of the publications in which most of the articles about CRIS appear. The main three are Grey Journal, Scientometrics, and Journal of Applied Poultry Research. Out of the 25 journals shown, four have a rank of Q1 (16\%), three are Q2 (12\%), six are Q3 (24\%), and four are Q4 $(16 \%)$ in WoS; the remaining eight journals (32\%) are indexed in Scopus. In general, this shows the variety of spaces in which the topic appears, also having academic quality as a shared characteristic.

TABLE III

RESEARCH AREAS

\begin{tabular}{|l|l|l|}
\hline \multicolumn{1}{|c|}{$\begin{array}{c}\text { Research } \\
\text { Areas }\end{array}$} & $\begin{array}{c}\text { Number } \\
\text { of } \\
\text { Articles }\end{array}$ & \multicolumn{1}{c|}{ ID $^{\mathbf{a}}$} \\
\hline $\begin{array}{l}\text { Information } \\
\text { Science \& } \\
\text { Library Science }\end{array}$ & $16(48 \%)$ & $\begin{array}{l}{[\mathrm{S} 1],[\mathrm{S} 4],[\mathrm{S} 5],[\mathrm{S} 10],[\mathrm{S} 11],} \\
{[\mathrm{S} 21],[\mathrm{S} 15],[\mathrm{S} 19],[\mathrm{S} 20],} \\
{[\mathrm{S} 25],[\mathrm{S} 27],[\mathrm{S} 31]}\end{array}$ \\
\hline $\begin{array}{l}\text { Computer } \\
\text { Science }\end{array}$ & $11(33 \%)$ & $\begin{array}{l}{[\mathrm{S} 2],[\mathrm{S} 3],[\mathrm{S} 6],[\mathrm{S} 8],[\mathrm{S} 9],} \\
{[\mathrm{S} 16],[\mathrm{S} 18],[\mathrm{S} 26],[\mathrm{S} 28],} \\
{[\mathrm{S} 29],[\mathrm{S} 33]}\end{array}$ \\
\hline Agriculture & $3(10 \%)$ & {$[\mathrm{S} 17],[\mathrm{S} 30],[\mathrm{S} 32]$} \\
\hline Education & $1(3 \%)$ & {$[\mathrm{S} 12]$} \\
\hline $\begin{array}{l}\text { Environmental } \\
\text { Sciences \& } \\
\text { Ecology }\end{array}$ & $1(3 \%)$ & {$[\mathrm{S} 14]$} \\
\hline Physics & $1(3 \%)$ & {$[\mathrm{S} 7]$} \\
\hline
\end{tabular}

${ }^{\mathrm{a}}$ Article number on the database of the systematic mapping.

TABLE IV

PUBLICATION JOURNALS

\begin{tabular}{|l|l|l|l|l|}
\hline \multicolumn{1}{|c|}{ Journal } & $\begin{array}{c}\text { Cite } \\
\text { Score }\end{array}$ & $\begin{array}{c}\text { SCImago } \\
\text { Journal } \\
\text { Rank }\end{array}$ & $\begin{array}{c}\text { Number } \\
\text { of } \\
\text { Articles }\end{array}$ & \multicolumn{1}{|c|}{ ID $^{\mathbf{f}}$} \\
\hline $\begin{array}{l}\text { Electronic } \\
\text { Library }\end{array}$ & 1.11 & 0.48 & 1 & {$[\mathrm{~S} 1]$} \\
\hline $\begin{array}{l}\text { Environmental } \\
\text { Science and } \\
\text { Policy }\end{array}$ & 3.90 & 1.66 & 1 & {$[\mathrm{~S} 14]$} \\
\hline $\begin{array}{l}\text { Expert Systems } \\
\text { with } \\
\text { Applications }\end{array}$ & 4.70 & 1.43 & 1 & {$[\mathrm{~S} 26]$} \\
\hline
\end{tabular}

\begin{tabular}{|c|c|c|c|c|}
\hline F1000Research ${ }^{\mathrm{e}}$ & 1.20 & 0.77 & 2 & [S2], [S9] \\
\hline Grey Journal $^{\mathrm{e}}$ & 0.15 & 0.12 & 4 & $\begin{array}{l}{[\mathrm{S} 5],[\mathrm{S} 19],} \\
{[\mathrm{S} 23],[\mathrm{S} 24]}\end{array}$ \\
\hline $\begin{array}{l}\text { International } \\
\text { Journal of } \\
\text { Software } \\
\text { Engineering } \\
\text { and Knowledge } \\
\text { Engineering }\end{array}$ & 0.59 & 0.18 & 1 & [S8] \\
\hline $\begin{array}{l}\text { Journal of } \\
\text { Applied Poultry } \\
\text { Research }^{\mathbf{b}}\end{array}$ & 0.96 & 0.57 & 3 & $\begin{array}{l}{[\mathrm{S} 17],} \\
{[\mathrm{S} 30],} \\
{[\mathrm{S} 32]}\end{array}$ \\
\hline $\begin{array}{l}\text { Journal of } \\
\text { Documentation }^{c}\end{array}$ & 1.47 & 0.70 & 1 & {$[S 27]$} \\
\hline $\begin{array}{l}\text { Journal of } \\
\text { Informetrics }^{\mathbf{a}}\end{array}$ & 2.99 & 2.03 & 1 & [S28] \\
\hline $\begin{array}{l}\text { Journal of } \\
\text { Librarianship } \\
\text { and Information } \\
\text { Science }^{\mathbf{c}}\end{array}$ & 1.24 & 0.82 & 1 & {$[\mathrm{~S} 25]$} \\
\hline $\begin{array}{l}\text { Journal of the } \\
\text { Association for } \\
\text { Information } \\
\text { Science and } \\
\text { Technology }\end{array}$ & 2.74 & 1.27 & 1 & [S6] \\
\hline $\begin{array}{l}\text { Journal of } \\
\text { Universal } \\
\text { Computer } \\
\text { Science }^{\mathrm{d}} \\
\end{array}$ & 0.98 & 0.31 & 1 & [S18] \\
\hline $\begin{array}{l}\text { LIBER } \\
\text { Quarterly }^{\mathrm{e}}\end{array}$ & 0.82 & 0.40 & 1 & [S11] \\
\hline $\begin{array}{l}\text { Library } \\
\text { Resources and } \\
\text { Technical } \\
\text { Services }\end{array}$ & 0.58 & 0.25 & 1 & [S13] \\
\hline $\begin{array}{l}\text { New Review of } \\
\text { Information } \\
\text { Networking }\end{array}$ & 0.29 & 0.23 & 1 & [S12] \\
\hline $\begin{array}{l}\text { OCLC Systems } \\
\text { and Services }\end{array}$ & 0.66 & 0.26 & 1 & [S22] \\
\hline $\begin{array}{l}\text { Physics of } \\
\text { Particles and } \\
\text { Nuclei Letters }\end{array}$ & 0.56 & 0.40 & 1 & [S7] \\
\hline $\begin{array}{l}\text { Profesional de } \\
\text { la Informacion }\end{array}$ & 1.01 & 0.54 & 1 & [S21] \\
\hline $\begin{array}{l}\text { Program- } \\
\text { electronic } \\
\text { Library and } \\
\text { Information } \\
\text { Systems }^{\text {d }}\end{array}$ & 1.50 & 0.39 & 1 & [S29] \\
\hline $\begin{array}{l}\text { Research } \\
\text { Evaluation }^{\text {a }}\end{array}$ & 2.14 & 1.08 & 1 & {$[\mathrm{~S} 20]$} \\
\hline $\begin{array}{l}\text { Revista } \\
\text { Espanola de } \\
\text { Documentacion } \\
\text { Cientifica }^{\mathbf{c}} \\
\end{array}$ & 0.65 & 0.35 & 1 & [S4] \\
\hline Scientometrics $^{\mathrm{b}}$ & 2.30 & 1.15 & 3 & $\begin{array}{l}\text { [S3], [S16], } \\
{[\mathrm{S} 33]}\end{array}$ \\
\hline Serials $^{\mathrm{e}}$ & & & 1 & {$[\mathrm{~S} 15]$} \\
\hline $\begin{array}{l}\text { Serials } \\
\text { Librarian }^{\mathrm{e}}\end{array}$ & 0.48 & 0.36 & 1 & {$[\mathrm{~S} 10]$} \\
\hline Serials Review ${ }^{\mathrm{d}}$ & 0.53 & 0.35 & 1 & [S31] \\
\hline
\end{tabular}




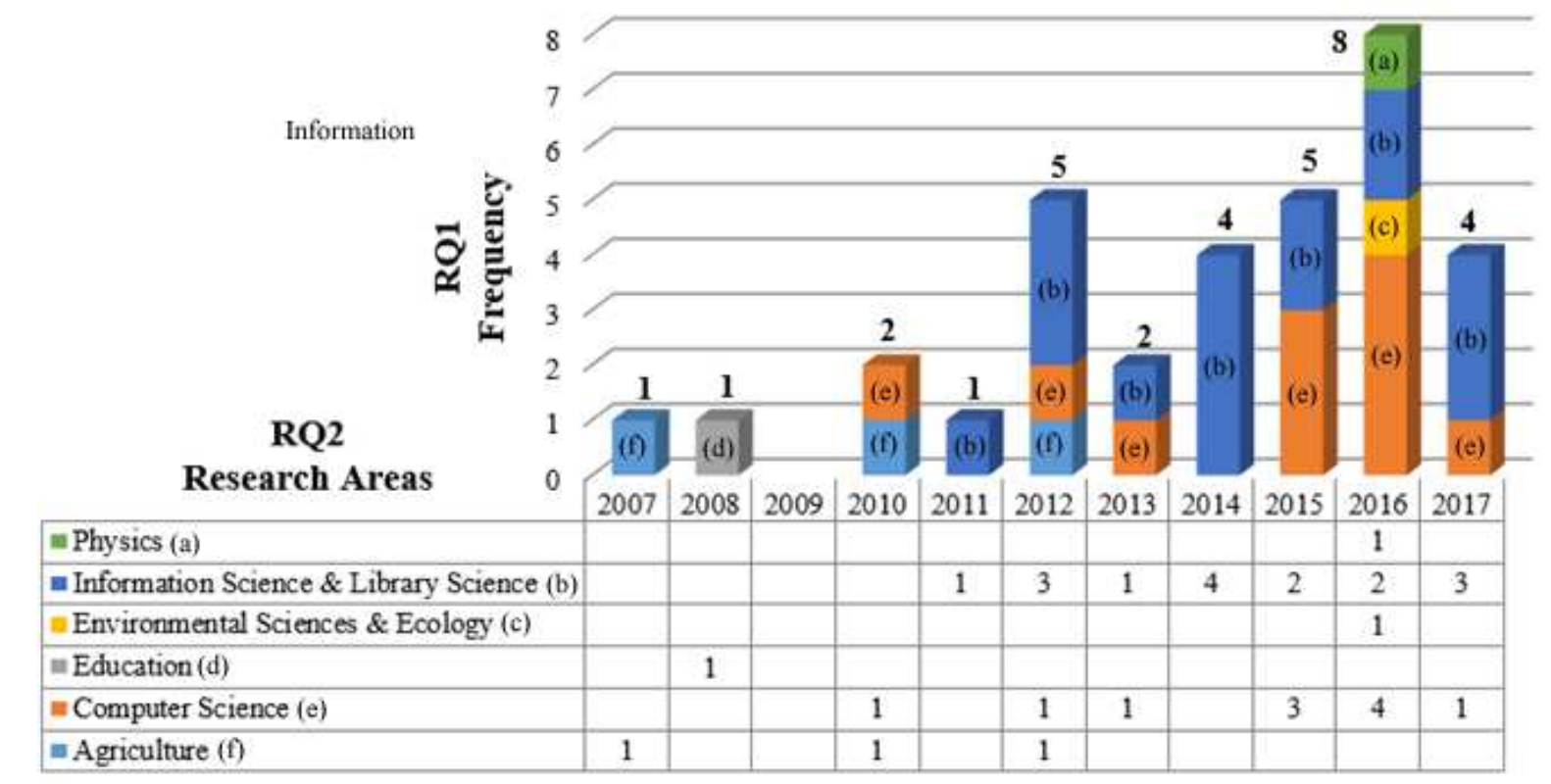

Fig. 3 Publications by year and research areas [45]

\section{Countries (RQ3)}

From the data of the institutions the authors are affiliated with, a map was generated showing the geographical distribution of the studies covering CRIS. Figure 4 shows colored dots indicating the countries in which the articles were published. The size of the circles represents the number of articles.

The largest concentration of publications is found in Europe, but there is also representation from North America and Asia. The region with the most publications was the United Kingdom, with seven (21\%), followed by Slovenia with five (15\%), Spain with five (15\%), and the United States with four (12\%) as presented in Table V and Figure 4. The publications of each country come mainly from universities, either from a university department or a research institute. Since the 1990s the universities of the world have been developing CRIS in various ways, depending on the organizations and countries involved [4]. In light of CRIS research being primarily Europe-centric, important areas of opportunity for global collaboration, cooperation and exchange are wide open for the rest of the continents.

\section{E. Institutions (RQ4)}

The main institution or organizations publishing about CRIS are based in the United Kingdom and the United States. From the data analysis, it was found that the National Institute of Food and Agriculture - USDA (United States) has the most presence, with three articles [S17], [S30] and [S32], all of them published in the Journal of Applied Poultry Research and authored by Richard Reynnells. These articles touch on the use of CRIS to provide solid information in the documentation of the activities of the institute. Next, there is Brunel University London (United Kingdom), with two published articles [S10] and [S31] by author David Walters. The first article describes how the University library maximized its ability to issue reports using the research information found in the Symplectic Elements $\odot$ instance, in conjunction with other open data sources, to establish efficient data management of the institution's open publications. The second article states there is increasingly more funding for open access publication policies, which has resulted in librarians managing such funds or making sure a wide variety of policies are observed. It shares a vision of the management process of these new tasks, how to change the perception of the parties involved and how to face future challenges. Rutherford Appleton Laboratory (United Kingdom) is also present with two articles, [S5] and [S12], by Keith Jeffery. In the first article, the author proposes a three-layered model with discovery metadata created from the CERIF contextual layer, while in the second article he presents a model for the use of CERIF that allows interoperability between CRIS instances by providing metadata describing publications with formal syntax and declared semantics (See Table V). It was precisely in Europe where the basis for CRIS [6] and the European standard for research information first appeared: CERIF in 1991 [5]; and it was in the United States that CRIS was founded at the National Institute of Food and Agriculture - USDA, almost at the same time as in the European Union. By focusing on a few institutions, research on CRIS topics shows areas of opportunity in terms of interinstitutional collaboration and exchanges of frameworks, methods, models, processes, and standards to enhance their operation.

\section{F. Research Approaches (RQ5)}

As mentioned above, the classification proposed for engineering studies [13] was adapted to categorize the studies analyzed according to the research's approach. The adaptation was to the fourth category, Conceptual papers, emphasizing on the theoretical orientation of the study. The final options were: (a) Validation research: the models, frameworks, methods, processes or others, are new and have not been implemented in practice; (b) Evaluation research: the models, framework, methods, processes or others have been implemented in the practice and have been evaluated or are in the process of evaluation; (c) Solution proposal: they propose a solution to a problem that could be a new model, 
framework, method, process or other, or an improvement to existing ones; (d) Conceptual papers: they structure the field of study in the form of taxonomy or conceptual framework; (e) Opinion papers: they express the personal opinion of an author about the models, framework, methods, processes or others, or about how some processes should be carried out; and (f) Experience papers: they explain how a model, method or process has been applied in practice, from the personal experience of the author. In the analysis of the primary studies, not one was found with an approach different to those proposed in the classification.

TABLE V

Publishing COUNTRIES AND INSTITUTIONS

\begin{tabular}{|c|c|c|c|}
\hline Country & $\begin{array}{c}\begin{array}{c}\text { Number } \\
\text { of } \\
\text { Articles }\end{array} \\
\end{array}$ & ID $^{\mathbf{a}}$ & Institution \\
\hline Austria & 1 & [S24] & $\begin{array}{l}\text { Austrian Academic Library } \\
\text { Consortium }\end{array}$ \\
\hline \multirow[t]{2}{*}{ Germany } & \multirow[t]{2}{*}{2} & [S8] & $\begin{array}{l}\text { German Research Center for } \\
\text { Artificial Intelligence (DFKI } \\
\text { GmbH) }\end{array}$ \\
\hline & & [S11] & $\begin{array}{l}\text { Karlsruhe Institute of } \\
\text { Technology (KIT), KIT Library }\end{array}$ \\
\hline Iran & 1 & [S29] & $\begin{array}{l}\text { Iranian Research Institute for } \\
\text { Information Science and } \\
\text { Technology }\end{array}$ \\
\hline Italy & 1 & [S19] & $\begin{array}{l}\text { Library sciences, Sapienza } \\
\text { University of Rome }\end{array}$ \\
\hline $\begin{array}{l}\text { Netherlan } \\
\text { ds }\end{array}$ & 1 & [S33] & CWTS, Leiden University \\
\hline Portugal & 1 & [S2] & $\begin{array}{l}\text { FCCN, Fundação para a } \\
\text { Ciência e Tecnologia }\end{array}$ \\
\hline $\begin{array}{l}\text { Russian } \\
\text { Federation }\end{array}$ & 1 & [S7] & $\begin{array}{l}\text { Joint Institute for Nuclear } \\
\text { Research, Dubna }\end{array}$ \\
\hline $\begin{array}{l}\text { Saudi } \\
\text { Arabia }\end{array}$ & 1 & [S9] & $\begin{array}{l}\text { King Abdullah University of } \\
\text { Science and Technology } \\
\text { (KAUST), KAUST Library }\end{array}$ \\
\hline \multirow[t]{2}{*}{ Serbia } & \multirow[t]{2}{*}{2} & [S3] & $\begin{array}{l}\text { Department of Mathematics and } \\
\text { Informatics, Faculty of Sciences, } \\
\text { University of Novi Sad }\end{array}$ \\
\hline & & [S13] & $\begin{array}{l}\text { Faculty of Education, } \\
\text { University of Novi Sad }\end{array}$ \\
\hline \multirow[t]{2}{*}{ Slovakia } & 1 & [S23] & $\begin{array}{l}\text { Slovak Centre of Scientific and } \\
\text { Technical Information, ICT } \\
\text { division }\end{array}$ \\
\hline & & [S6] & $\begin{array}{l}\text { Faculty of Social Sciences, } \\
\text { University of Ljubljana }\end{array}$ \\
\hline
\end{tabular}

The research approaches for the CRIS topic fall into Evaluation Research, that is, studies that have already been implemented in practice and a full or partial evaluation has been carried out. The statistics presented in Table VI and Figure 5 shows that the category Evaluation Research amounts to $58 \%$ (19 articles), followed by Conceptual Paper with 15\% (5), Solution Proposal with 12\% (4), Validation Research with 9\% (3) and Experience Papers with 6\% (2). References [10], [11], report that the primary studies analyzed are conceptual works or solution proposals without evaluation or experimental validation. Although both works apply software engineering, the first one does so in Software Product Line Variability, while the second employs

\begin{tabular}{|c|c|c|c|}
\hline \multirow{4}{*}{ Slovenia } & \multirow{4}{*}{5} & [S16] & $\begin{array}{l}\text { Agronomy Department, } \\
\text { Biotechnical Faculty, } \\
\text { University of Ljubljana }\end{array}$ \\
\hline & & [S25] & $\begin{array}{l}\text { Slovenian Research Agency } \\
\text { (ARRS) }\end{array}$ \\
\hline & & [S26] & $\begin{array}{l}\text { Institute of Information } \\
\text { Science }\end{array}$ \\
\hline & & [S28] & $\begin{array}{l}\text { Department of Physics, } \\
\text { Faculty of Natural Sciences } \\
\text { and Mathematics, University } \\
\text { of Maribor }\end{array}$ \\
\hline \multirow{5}{*}{ Spain } & \multirow{5}{*}{5} & {$[\mathrm{~S} 4]$} & $\begin{array}{l}\text { Departamento de } \\
\text { Biblioteconomía y } \\
\text { Documentación, Universitat de } \\
\text { Barcelona, Spain }\end{array}$ \\
\hline & & [S18] & $\begin{array}{l}\text { Information Engineering } \\
\text { Research Unit, Computer } \\
\text { Science Department, } \\
\text { University of Alcalá }\end{array}$ \\
\hline & & [S20] & $\begin{array}{l}\text { Philosophy Institute, Spanish } \\
\text { National Research Council }\end{array}$ \\
\hline & & {$[\mathrm{S} 21]$} & $\begin{array}{l}\text { Fundación Dialnet, } \\
\text { Universidad de la Rioja }\end{array}$ \\
\hline & & [S27] & $\begin{array}{l}\text { Department of Information } \\
\text { and Communication, } \\
\text { University of Granada }\end{array}$ \\
\hline \multirow{5}{*}{$\begin{array}{l}\text { The } \\
\text { United } \\
\text { Kingdom }\end{array}$} & \multirow{5}{*}{7} & {$[\mathrm{~S} 1]$} & $\begin{array}{l}\text { Centre for E-Research, } \\
\text { King's College London }\end{array}$ \\
\hline & & $\begin{array}{l}\text { [S5], } \\
{[\mathrm{S} 12]} \\
\end{array}$ & $\begin{array}{l}\text { Rutherford Appleton } \\
\text { Laboratory }\end{array}$ \\
\hline & & $\begin{array}{l}{[\mathrm{S} 10],} \\
{[\mathrm{S} 31]}\end{array}$ & Brunel University London \\
\hline & & {$[\mathrm{S} 15]$} & Cranfield University \\
\hline & & [S22] & Bingley \\
\hline \multirow[t]{2}{*}{$\begin{array}{l}\text { The } \\
\text { United } \\
\text { States }\end{array}$} & \multirow[t]{2}{*}{4} & [S14] & $\begin{array}{l}\text { Union of Concerned } \\
\text { Scientists }\end{array}$ \\
\hline & & $\begin{array}{l}{[\mathrm{S} 17],} \\
{[\mathrm{S} 30],} \\
{[\mathrm{S} 32]}\end{array}$ & $\begin{array}{l}\text { National Institute of Food } \\
\text { and Agriculture - USDA }\end{array}$ \\
\hline
\end{tabular}

${ }^{\mathrm{a}}$ Article number on the database of the systematic mapping. The database of the 33 analyzed articles in this systematic mapping of literature is available online at the following web address: http://doi.org/10.5281/zenodo.1094825

Gamification, which makes sense because, until a proposal that allows reduction of costs and delivery times and optimized processes is made, proposals are not built and applied in a real scenario. In the case of the present work, there is a trend of CRIS implementation to validate the contribution and the adequacy of a proposal previously built. This demonstrates that the adequacy or improvement of this type of systems is done on the fly and tested in systems already in place. When studies on CRIS are carried out, they present the implementation of a model, framework, method, process or other in practice (implementation of the solution), and the consequences in terms of benefits, advantages and disadvantages (evaluation of implementation). 


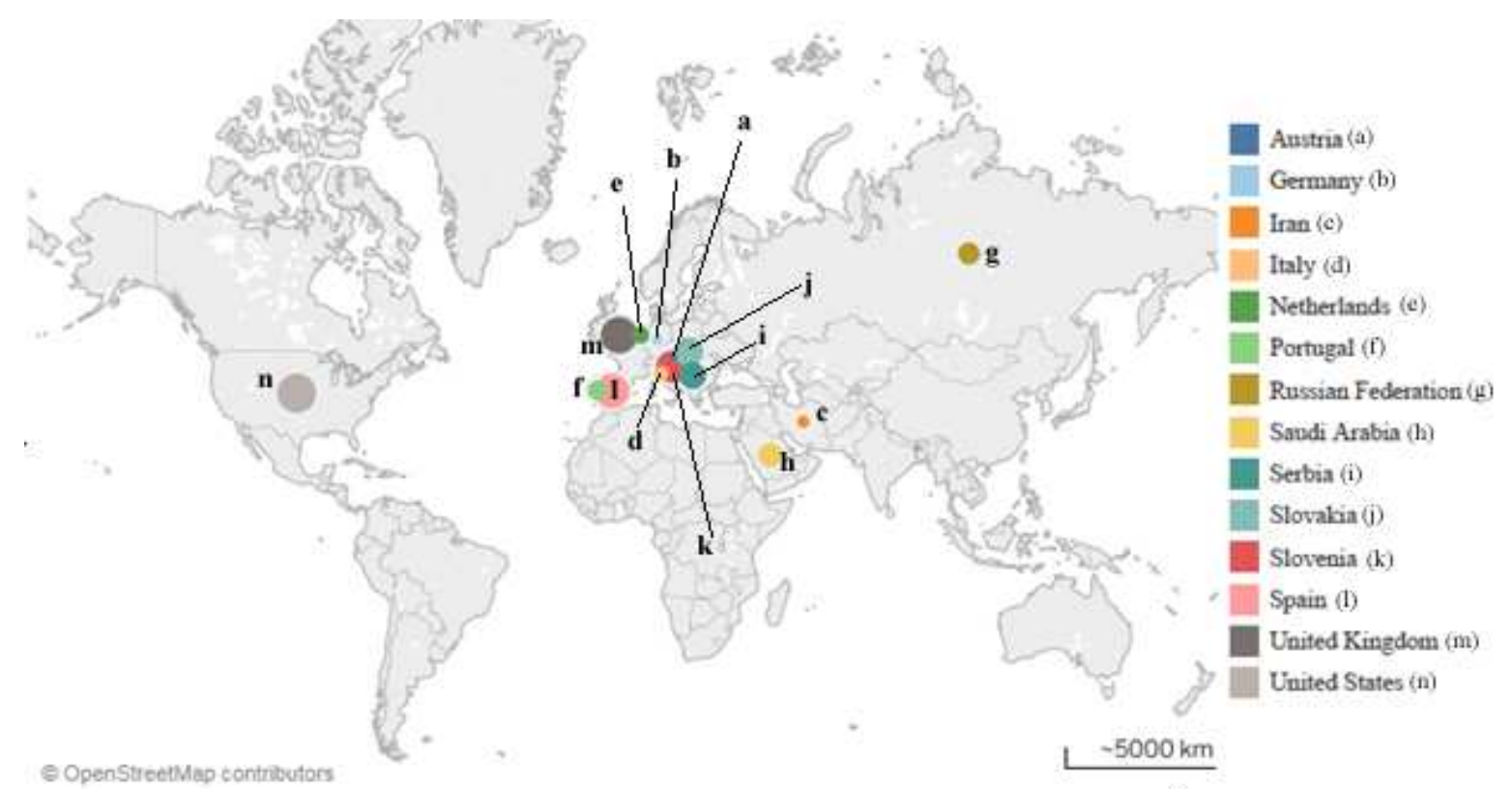

Fig. 4 Publications per country [46]. Map based on longitude and latitude. The circle's colors show each country, while their size indicates the number of articles

TABLE VI

RESEARCH APPROACHES

\begin{tabular}{|l|l|l|}
\hline \multicolumn{1}{|c|}{ Approaches } & $\begin{array}{c}\text { Number of } \\
\text { Articles }\end{array}$ & \multicolumn{1}{c|}{ ID $^{\mathbf{a}}$} \\
\hline $\begin{array}{l}\text { Conceptual } \\
\text { Paper }\end{array}$ & 5 & $\begin{array}{l}\text { [S16], [S17], [S29], [S30], } \\
\text { [S32] }\end{array}$ \\
\hline $\begin{array}{l}\text { Evaluation } \\
\text { Research }\end{array}$ & 19 & $\begin{array}{l}\text { [S1], [S2], [S3], [S4], [S6], } \\
\text { [S8], [S9], [S11], [S13], } \\
\text { [S14], [S15], [S20], [S22], } \\
\text { [S23], [S25], [S26], [S27], } \\
\text { [S28], [S33] }\end{array}$ \\
\hline $\begin{array}{l}\text { Experience } \\
\text { Papers }\end{array}$ & 2 & [S10], [S31] \\
\hline $\begin{array}{l}\text { Solution } \\
\text { Proposal }\end{array}$ & 4 & [S12], [S18], [S21], [S24] \\
\hline $\begin{array}{l}\text { Validation } \\
\text { Research }\end{array}$ & 3 & [S5], [S7], [S19] \\
\hline
\end{tabular}

${ }^{a}$ Article number on the database of the systematic mapping.

\section{G. Contributions (RQ6)}

The type of contribution of the articles was a classification that was created following the analysis strategy of the abstracts' keywords; in other words, a classification was created through cluster identification [33]. The results were seven possible options: (a) Framework, a software structure integrated by customizable and interchangeable components for the development of an application, that is, reusable design components that facilitate and speed the development of systems [17]; (b) Mapping, which consists of transferring a conceptual system or structure into a map, representing the parts of a whole; (c) Method, a procedure (therefore orderly and systematic) to arrive at a determined result or purpose; (d) Model, a theoretical scheme of a system, designed to facilitate understanding; (e) Process, a set of successive phases of a specific operation or task; (f) Classification, a taxonomy that allows a systematic ordering of a topic of study; and (g) Tool, an instrument to perform a specific task.
The contributions of CRIS are mostly oriented to create processes and models to strengthen research information management. From the studies analyzed, Table VII and Figure 6 show that the most frequent type of contribution was Process, with $36 \%$, followed by Model with $27 \%$, Framework, and Classification with $12 \%$ each, Mapping with 6\%, and finally Method and Tool with 3\%, respectively. This type of contributions coincides with the reported studies in the literature, of note being: Process [14], [15]; Model [16]; Framework [18]; Classification and Mapping [19], and Method and Tool [20]. One of the most representative articles on mapping in relation to the Process contribution states that a cluster analysis process was carried out on the bibliographic data of Slovenian researchers and the disciplines to which they belong, using their country's SICRIS, and from there it discussed the understanding of the structure of collaboration and cooperation in sciences and the research and development policies [15]. CRIS contribute to the global scientific community by providing mainly Processes (successive phases to carry out an operation) and Models (theoretical schemes), all to support research management according to international guidelines and practices.

TABLE VII

CONTRIBUTIONS OF THE STUDIES

\begin{tabular}{|l|l|l|}
\hline Contribution & $\begin{array}{l}\text { Number of } \\
\text { Articles }\end{array}$ & \multicolumn{1}{c|}{ ID $^{\mathbf{a}}$} \\
\hline Framework & 4 & {$[\mathrm{~S} 2],[\mathrm{S} 7],[\mathrm{S} 19],[\mathrm{S} 27]$} \\
\hline Mapping & 2 & {$[\mathrm{~S} 11],[\mathrm{S} 18]$} \\
\hline Method & 1 & {$[\mathrm{~S} 3]$} \\
\hline Model & 9 & $\begin{array}{l}{[\mathrm{S} 1],[\mathrm{S} 5],[\mathrm{S} 8],[\mathrm{S} 12],[\mathrm{S} 13],} \\
{[\mathrm{S} 23],[\mathrm{S} 26],[\mathrm{S} 28],[\mathrm{S} 29]}\end{array}$ \\
\hline Process & 12 & $\begin{array}{l}{[\mathrm{S} 4],[\mathrm{S} 6],[\mathrm{S} 9],[\mathrm{S} 10],[\mathrm{S} 14],} \\
{[\mathrm{S} 15],[\mathrm{S} 20],[\mathrm{S} 22],[\mathrm{S} 24],} \\
{[\mathrm{S} 25],[\mathrm{S} 31],[\mathrm{S} 33]}\end{array}$ \\
\hline Classification & 4 & {$[\mathrm{~S} 16],[\mathrm{S} 17],[\mathrm{S} 30],[\mathrm{S} 32]$} \\
\hline Tool & 1 & {$[\mathrm{~S} 21]$} \\
\hline
\end{tabular}

${ }^{\mathrm{a}}$ Article number on the database of the systematic mapping. 


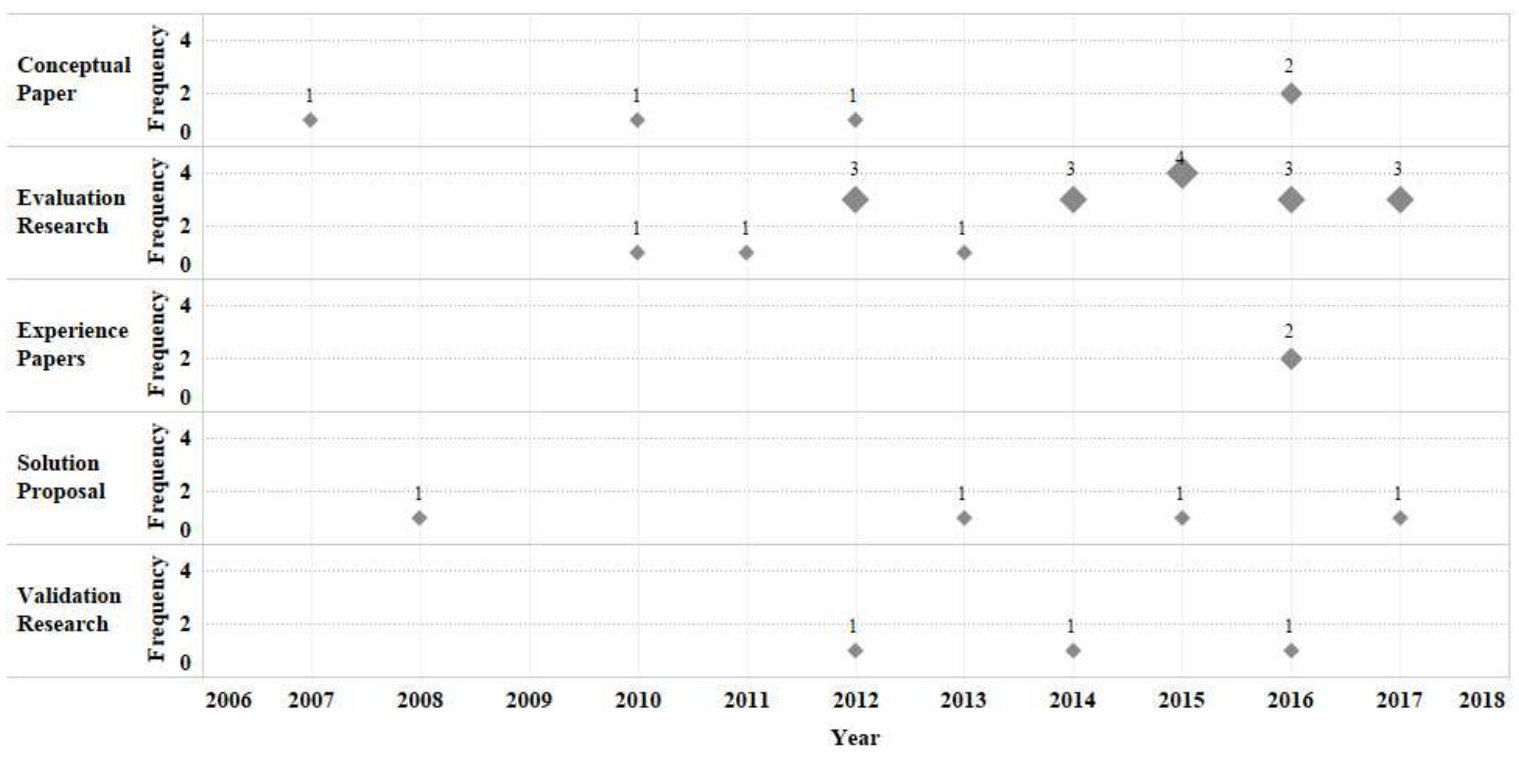

Fig. 5 Research approaches [47]. The size of the diamonds shows the number of articles that belong to each category

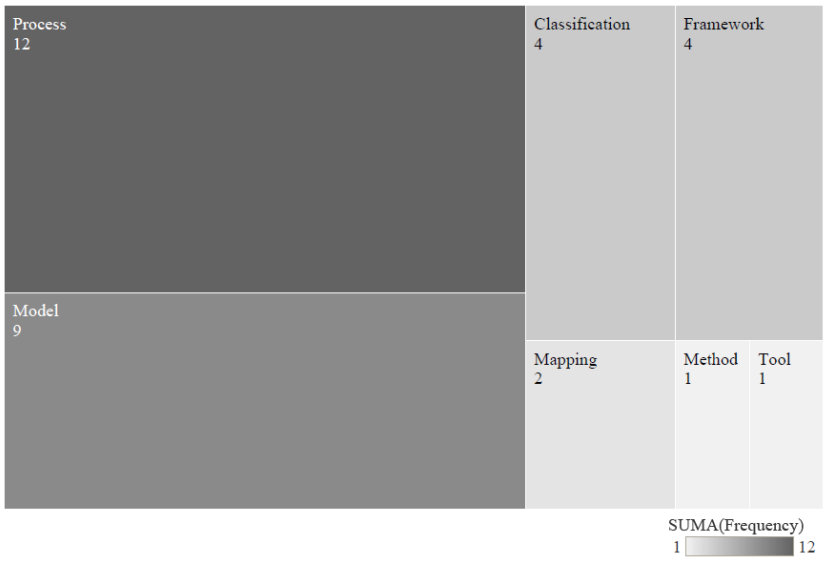

Fig. 6 Contributions of the studies [48]. The size of the rectangles shows the number of articles in each category.

\section{H. Topics and Keywords (RQ7)}

To identify the topics of each study, an analysis of abstracts and keywords was carried out; the results were four big sections: (a) Data Structure (DS): the article explained what CRIS was, what kind of information it stored and what was its data structure; (b) Applications (APP): described the applications for the information managed by CRIS and for what purposes they are used; (c) Communication / Interoperability (INT): covered topics about standards, protocols and identifiers designed to interconnect CRIS with other systems; and (d) Institutional Repository (IR): emphasized how CRIS connects to an Institutional Repository and the problems involved in the integration of both systems.

The research topics in relation to CRIS are focused on Applications and Data Structure. Table VIII and Figure 7 show the indicators of each topic: Applications (APP) with $33 \%$ of the studies, followed by Data Structure with $28 \%$, Communication / Interoperability with $21 \%$ and finally Institutional Repository with $18 \%$. Figure 8 shows a general overview of the production of topics related to CRIS, including their approaches and contributions. Also, from the 33 articles analyzed, 122 keywords from the authors were identified, the most frequent being Current Research
Information Systems with six mentions, CRIS with four, and Animal welfare and behavior, CERIF, Metadata, Multistate research committee, Ontologies and Open Access with three. Most of the publications are aimed at reporting the uses of this type of systems and the information they manage, having applications in various areas, sectors, and levels, such as libraries, universities [25], [26] and globally [27]. A representative article of the mapping in this topic $(A P P)$, indicated that citation data from about 86,443 publications from 8359 researchers working in the social and natural sciences since 1970 were used, all stored in SICRIS, with the purpose of showing that citation distributions derived from individual publications have Zipfian properties [49]. For the next topic, publications then aim to communicate what a CRIS is, the information it contains and its data structure: the Data Structure topic. In this regard, the literature indicates that there are systems that store information from scientific research [21] and provide search services to access this information and exchange data [22]; however, access and data types are restricted (data structures), so standards such as CRIS are needed to represent them in the field of scientific research. Aspects like interoperability and the connection of CRIS instances with institutional repositories are recognized as areas of opportunity for the CRIS topic. The use of open access to disseminate research information is also a topic that must be strengthened.

TABLE VIII

TOPICS OF STUDIES

\begin{tabular}{|l|l|l|}
\hline \multicolumn{1}{|c|}{ Contribution } & $\begin{array}{c}\text { Number of } \\
\text { Articles }\end{array}$ & \multicolumn{1}{c|}{ ID $^{\mathbf{a}}$} \\
\hline Applications & 11 & $\begin{array}{l}{[\mathrm{S} 3],[\mathrm{S} 4],[\mathrm{S} 6],[\mathrm{S} 14],} \\
{[\mathrm{S} 16],[\mathrm{S} 17],[\mathrm{S} 20],} \\
{[\mathrm{S} 28],[\mathrm{S} 30],[\mathrm{S} 31],[\mathrm{S} 32]}\end{array}$ \\
\hline $\begin{array}{l}\text { Communication / } \\
\text { Interoperability }\end{array}$ & 7 & $\begin{array}{l}{[\mathrm{S} 1],[\mathrm{S} 2],[\mathrm{S} 5],[\mathrm{S} 8],} \\
{[\mathrm{S} 9],[\mathrm{S} 18],[\mathrm{S} 27]}\end{array}$ \\
\hline Data Structure & 9 & $\begin{array}{l}{[\mathrm{S} 7],[\mathrm{S} 11],[\mathrm{S} 15],[\mathrm{S} 21],} \\
{[\mathrm{S} 23],[\mathrm{S} 25],[\mathrm{S} 26],} \\
{[\mathrm{S} 29],[\mathrm{S} 33]}\end{array}$ \\
\hline $\begin{array}{l}\text { Institutional } \\
\text { Repository }\end{array}$ & 6 & $\begin{array}{l}{[\mathrm{S} 10],[\mathrm{S} 12],[\mathrm{S} 13],} \\
{[\mathrm{S} 19],[\mathrm{S} 22],[\mathrm{S} 24]}\end{array}$ \\
\hline
\end{tabular}

${ }^{a}$ Article number on the database of the systematic mapping. 


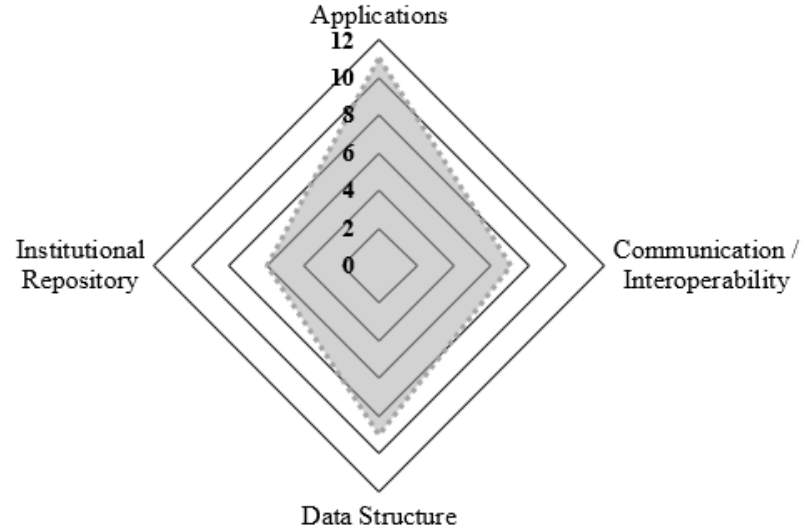

Fig. 7 Topics covered in the analyzed articles [50]

\section{CONCLUSIONS}

CRIS open up a panorama of possibilities for the management of the information related to research in any discipline, area, level, sector or context. In the last decade, studies in relation to CRIS have been conducted in specific research areas such as Information Science \& Library Science and Computer Science; however, publications about it are still incipient. From this perspective, this article analyzed articles that focused on CRIS (2007-2017), with the objective of identifying the research areas, countries and institutions in which these studies have been published, their research approaches, contributions and thematic issues addressed; knowing what type of research has been done and its contributions open up many possibilities to provide original knowledge that allows for the construction of frameworks and the identification of gaps to guide future works to explore the development, use, communication, interoperability and connection of CRIS with other systems and topics, such as the use of open access to share research information.

Also, the database of the articles analyzed can be used as support for other studies that deal with the management of research in an automated way: studies that require a state of the art in this subject; that need to identify frameworks, methods, models, processes, and tools to implement CRIS; that need to measure the impact of their scientific productivity; and that require to know cases of success in the installation, configuration and operation of CRIS.

For the systematic mapping search strategy, the WoS and Scopus databases and the document type were delimited. This could prove a limitation for the generalization of the information presented, but at the same time, it represents an opportunity for future mapping that contributes to the topic of CRIS.

This article demonstrates that there are areas of opportunity in research about CRIS, such as the expansion of coverage in other research areas other than Information Science \& Library Science and $f$, and in other countries outside Europe and North America, as well to the possibilities of collaboration, diffusion and global exchange of the contributions originated, and the coverage towards open access issues. An invitation to add to this subject is made, to ensure the management of research information for the benefit of the scientific community and society at large.

\section{ACKNOWLEDGMENT}

This research is a product of the Project 266632 "Laboratorio Binacional para la Gestión Inteligente de la Sustentabilidad Energética y la Formación Tecnológica" ["Bi-National Laboratory on Smart Sustainable Energy Management and Technology Training"], funded by the CONACYT SENER Fund for Energy Sustainability (Agreement: S0019201401).

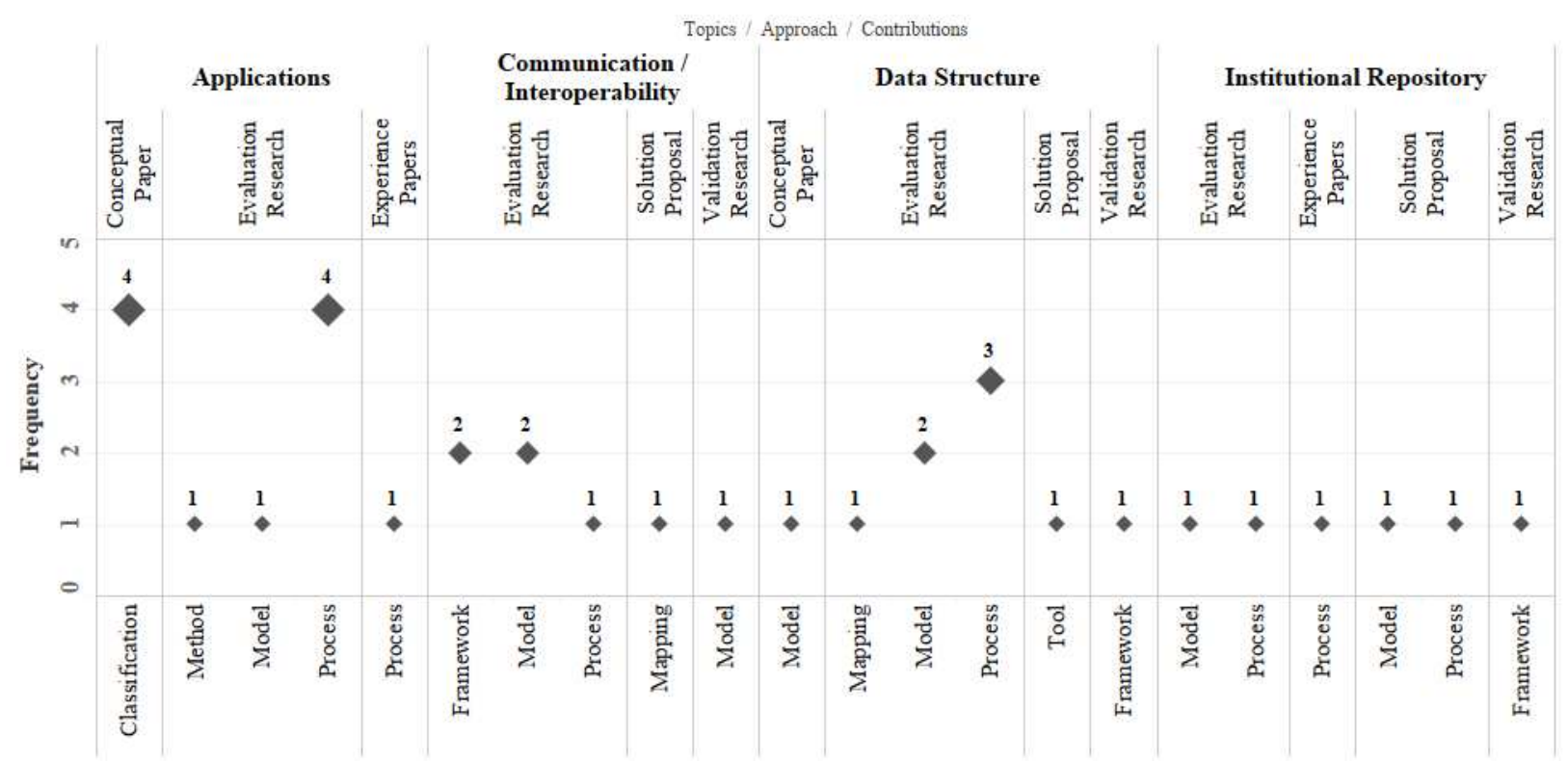

Fig. 8 Topics, approaches and contributions of research about CRIS [51]. The size of the diamonds indicates the number of articles belonging to each category 


\section{REFERENCES}

[1] L. M. Ribeiro, P. De Castro, and M. Mennielli, "Surveying CRIS and IR across Europe," in EUNIS 2015, The Journey to Discovery, June 2015, pp. 10-12.

[2] E. Simons, M. Jetten, M. Van Berchum, M. Messelink, H. Schoonbrood, and M. Wittenberg, "The Important Role of CRIS's for Registering and Archiving Research Data. The RDS-project at Radboud University (the Netherlands) in Cooperation with Dataarchive DANS," Procedia Computer Science, vol. 106, pp. 321-328, 2017. doi: 10.1016/j.procs.2017.03.031

[3] M. D. Wilkinson, et al., "The FAIR Guiding Principles for scientific data management and stewardship," Sci, 2016, data3:160018. doi: 10.1038/sdata.2016.18

[4] A. Leiva-Mederos, J. A. Senso, Y. Hidalgo-Delgado, and P. Hipola, "Working framework of semantic interoperability for CRIS with heterogeneous data sources," Journal of Documentation, vol. 73, issue 3, pp. 481-499, 2017. doi: 10.1108/JD-07-2016-0091

[5] B. Jörg, K. Jeffery, G. Van Grootel, A. Asserson, J. Dvorak, and H. Rasmussen. (2012) CERIF 1.3 full data model (FDM) introduction and specification. [Online]. Available www.eurocris.org/Uploads/Web\%20pages/CERIF-

1.3/Specifications/CERIF1.3_FDM.pdf

[6] L. Ivanović, D. Ivanović, and D. Surla, "Notes on operations," Library Resources \& Technical Services, vol. 56, issue 2, pp. 104112, 2012. doi: 10.5860/lrts.56n2.104

[7] B. Wolf, M. Szerencsits, H. Gaus, C. E. Müller, and J. Heb, "Developing a Documentation System for Evaluating the Societal Impact of Science," Procedia Computer Science, vol. 33, pp. 289296, 2014. doi: 10.1016/j.procs.2014.06.046

[8] D. Walters, M. Ritchie, and M. Kilb, "CRIS Power! Taming the Reporting Requirements of Open Access," The Serials Librarian, vol. 70, issue 1-4, pp- 229-235, 2016. doi: 10.1080/0361526X.2016.1160306

[9] S. Hanna, H. Jaber, A. Almasalmeh, and F. Jaber, "Reducing the Gap between Software Engineering Curricula and Software Industry in Jordan," Journal of Software Engineering and Applications, vol. 7, issue 7, pp. 602-616, 2014. doi: 10.4236/jsea.2014.77056

[10] S. Mujtaba, K. Petersen, R. Feldt, and M. Mattsson, "Software product line variability: A systematic mapping study", Information and Software Technology, vol. 53, issue 5, pp. 407-423, May 2011. doi: 10.1016/j.infsof.2010.12.003

[11] O. Pedreira, F. García, N., Brisaboa, and M. Piattini, "Gamification in software engineering - A systematic mapping," Information and Software Technology, vol. 57, issue 1, pp. 157-168, 2014. doi: 10.1016/j.infsof.2014.08.007 2014

[12] K. Petersen, S. Vakkalanka, and L. Kuzniarz, "Guidelines for conducting systematic mapping studies in software engineering: An update," Information and Software Technology, vol. 64, pp. 1-18, 2015. doi:10.1016/j.infsof.2015.03.007

[13] R. Wieringa, N. Maiden, N. Mead, and C. Rolland, "Requirements engineering paper classification and evaluation criteria: a proposal and a discussion," Requirements. Eng., vol. 11, issue 1, pp. 102-107, 2006. doi: 10.1007/s00766-005-0021-6

[14] R. Drummond, "RIMS Revisited: The Evolution of the Research Impact Measurement Service at UNSW," Australian Academic \& Research Libraries, vol. 45, issue 4, pp. 309-322, 2014. doi: 10.1080/00048623.2014.945065

[15] L. Kronegger, F. Mali, A. Ferligoj, and P. Doreian, "Classifying scientific disciplines in slovenia: A study of the evolution of collaboration structures," Journal of the Association for Information Science and Technology, vol. 66, issue 2, pp. 321-329, 2015. doi:10.1002/asi.23171 (2015)

[16] R. M. Marsh, "The role of institutional repositories in developing the communication of scholarly research," OCLC Systems \& Services: International digital library perspectives, vol. 31, issue 4, pp.163195, 2015. doi: 10.1108/OCLC-04-2014-0022

[17] A. Baez-Ibarra, N. Arellanes-Cancino, and A. Sosa-Perdomo, "Efectividad de la aplicación de metodologías ágiles para el desarrollo de apps móviles. Un caso de estudio," Revista de Sistemas Computacionales y TIC's, vol. 2, issue 6, pp. 45-66, 2016. Available: http://www.ecorfan.org/spain/researchjournals/Sistemas_Computacio nales_y_TICs/vol2num6/Revista_de_Sistemas_Computacionales_y_ TIC\%60S_V2_N6_7.pdf
[18] C. Maican, and R. Lixăndroiu, "Rapid application development for a research information system: a case study," Bulletin of the Transilvania University of Brașov Series V: Economic Sciences, vol. 8 , issue $57,2015$.

[19] M. Karlovcec, D. Mladenic, M. Grobelnik, and M. Jermol, "Conceptualization of science using collaboration and competences," The Electronic Library, vol. 34, issue: 1, pp.2-23, 2016. doi: 10.1108/EL-01-2014-0015

[20] R. Kirkwood, "Collection development or data-driven content curation? An exploratory project in Manchester," Library Management, vol. 37, issue 4/5, pp. 275-284, 2016. doi: 10.1108/LM-05-2016-0044

[21] V. Penca, S. Nikolić, , D. Ivanović, Z. Konjović, and D. Surla, "SRU/W-based CRIS systems search profile," Program, vol. 48, issue 2, pp.140-166, 2014. doi: 10.1108/PROG-07-2012-0040

[22] J. Dvorak, and B. Jörg. (2013) CERIF 1.5 XML Data Exchange Format Specification. [Online]. Available: www.eurocris.org/Uploads/Web\%20pages/CERIF1.5/CERIF1.5_XML_preview.pdf

[23] A. Clements, and V. Mccutcheon, "Research data meets research information management: two case studies using (a) Pure CERIFCRIS and (b) EPrints repository platform with CERIF extensions," Procedia Computer Science, vol. 33, pp. 199-206, 2014. doi: 10.1016/j.procs.2014.06.033

[24] P. Castro, K. Shearer, and F. Summann, "The gradual merging of repository and CRIS solutions to meet institutional research information management requirements," Procedia Computer Science, vol. 33, pp. 39-46, 2014. doi: 10.1016/j.procs.2014.06.007

[25] M. A. Kennan, S. Corrall, and W. Afzal, "“Making space” in practice and education: research support services in academic libraries", Library Management, vol. 35, issue: 8/9, pp.666-683, 2014. doi: 10.1108/LM-03-2014-0037

[26] N. González-Fernández-Villavicencio, M. I. Domínguez-Aroca, ACalderón-Rehecho, and P. García- Hernández, "¿Qué papel juegan los bibliotecarios en las altmetrics?," Anales de Documentación, vol. 18, issue 2, pp. 1-19, 2015. doi: 10.6018/analesdoc.18.2.222641

[27] M. Ojsteršek, J. Brezovnik, M. Kotar, M. Ferme, G. Hrovat, A. Bregant, and M. Borovič, "Establishing of a Slovenian open access infrastructure: a technical point of view," Program, vol. 48, issue: 4, pp. 394-412, 2014. doi: 10.1108/PROG-02-2014-0005

[28] J. Schöpfela, H. Prosta, and V. Rebouillatb, "Research Data in Current Research Information Systems," Procedia Computer Science, vol. 106, pp. 305 - 320, 2017. doi: 10.1016/j.procs.2017.03.030

[29] P. De Castro, and M. Mennielli, "Recent work by the euroCRIS best Practice/DRIS task group: A way forward for engaging with the CRIS community," Procedia Computer Science, vol. 33, pp. 60-67, 2014. doi:10.1016/j.procs.2014.06.010

[30] I. Nevolin, and A. Kozyrev, "Developing CRIS module for technology transfer," Procedia Computer Science, vol. 33, pp. 158162, 2014. doi:10.1016/j.procs.2014.06.026

[31] G. Walsham, and S. Sahay, "Research on Information Systems in Developing Countries: Current Landscape and Future Prospects," Information Technology for Development, vol. 12, issue 1, pp. 7-24, 2006. doi: $10.1002 /$ itdj. 20020

[32] B. Kitchenham, and S. Charters, "Guidelines for Performing Systematic Literature Reviews in Software Engineering," Keele University and Durham University, EBSE 2007-001, 2007.

[33] K. Petersen, R. Feldt, S. Mujtaba, and M. Mattsson, "Systematic Mapping Studies in Software Engineering," in Proceedings of the 12th International Conference on Evaluation and Assessment in Software Engineering (EASE'08), 2008, pp. 68-77.

[34] A. Velásquez-Durán, and M. S. Ramírez, "Research Management Systems: Systematic Mapping of Literature (2007-2017) - Process of systematic mapping," Zenodo, 2017. doi:10.5281/zenodo.1095847

[35] A. W. Harzing, and S. Alakangas, "Google Scholar, Scopus and the Web of Science: a longitudinal and cross-disciplinary comparison," Scientometrics, vol. 106, pp. 787-804, 2016. doi: 10.1007/s11192015-1798-9

[36] P. Mongeon, and A. Paul-Hus, "The journal coverage of Web of Science and Scopus: a comparative analysis," Scientometrics, vol. 106, pp. 213-228, 2016. doi: 10.1007/s11192-015-1765-5

[37] É. Archambault, D. Campbell, Y. Gingras, and V. Larivie`re, "Comparing bibliometric statistics obtained from the Web of Science and Scopus," Journal of the American Society for Information Science and Technology, vol. 60, issue 7, pp. 1320-1326, 2009. doi:10.1002/asi.21062 
[38] A. Zancarano, J. L. Todesco, and F. Ramos, "A Bibliometric Mapping of Open Educational Resources," International Review of Research in Open and Distributed Learning, vol. 16, issue 1, pp. 123, 2015. doi: 10.19173/irrodl.v16i1.1960

[39] (2017) Clarivate: Web of Sciencie website. [Online]. Available: https://www.clarivate.com/products/web-of-science

[40] (2017) Scopus website [Online]. https://www.elsevier.com/solutions/scopus

[41] B. Kitchenham, P. Brereton, and D. Budgen, "Mapping study completeness and reliability - a case study," in EASE IET - The Institute of Engineering and Technology / IEEE Xplore, 2012, pp. 126-135. Available: trier.de/db/conf/ease/ease2012.html\#KitchenhamBB12

[42] A. Velásquez-Durán, and M. S. Ramírez, "CRIS Metadata [Data set]," Zenodo, 2017, México. doi:10.5281/zenodo.1094825

[43] A. Velásquez-Durán, and M. S. Ramírez, "Research Management Systems: Systematic Mapping of Literature (2007-2017) - Number of articles included during the search and qualitative evaluation process of the study," Zenodo, 2017. doi:10.5281/zenodo.1095852

[44] R. Reynnells, "Washington update," Journal of Applied Poultry Research, vol. 16, issue 1, pp. 70-76, 2007. doi: 10.1093/japr/16.1.70

[45] A. Velásquez-Durán, and M. S. Ramírez, "Research Management Systems: Systematic Mapping of Literature (2007-2017) Publications by year and research areas," Zenodo, 2017. doi: 10.5281/zenodo. 1095856
[46] A. Velásquez-Durán, and M. S. Ramírez, "Research Management Systems: Systematic Mapping of Literature (2007-2017) Publications per 10.5281/zenodo. 1095858

[47] A. Velásquez-Durán, and M. S. Ramírez, "Research Management Systems: Systematic Mapping of Literature (2007-2017) - Research approaches," Zenodo, 2017. doi:10.5281/zenodo.1095862

[48] A. Velásquez-Durán, and M. S. Ramírez, "Research Management Systems: Systematic Mapping of Literature (2007-2017) Contributions of the studies," Zenodo, 2017. doi:10.5281/zenodo. 1095866

[49] M. Perc, "Zipf's law and log-normal distributions in measures of scientific output across fields and institutions: 40 years of slovenia's research as an example," Journal of Informetrics, vol.4, issue 3, pp. 358-364, 2010. doi:10.1016/j.joi.2010.03.001

[50] A. Velásquez-Durán, and M. S. Ramírez, "Research Management Systems: Systematic Mapping of Literature (2007-2017) - Topics covered in the analyzed articles," Zenodo, 2017. doi: $10.5281 /$ zenodo. 1095868

[51] A. Velásquez-Durán, and M. S. Ramírez, "Research Management Systems: Systematic Mapping of Literature (2007-2017) - Topics, approaches and contributions of research about CRIS," Zenodo, 2017. doi:10.5281/zenodo.1095872 